\title{
Early Maladaptive Schemas and Aggression Based on the Birth Order of Children
}

\author{
Elmira Fasihi Ardebili ${ }^{1} \&$ Fatemeh Golshani ${ }^{2}$ \\ ${ }^{1}$ MD of General Psychology, Department of Psychology, Faculty of Education and Psychology, Islamic Azad \\ University of Central Tehran Branch, Tehran, Iran \\ ${ }^{2} \mathrm{PhD}$ of General Psychology, Department of Psychology, Faculty of Education and Psychology, Islamic Azad \\ University of Central Tehran Branch, Tehran, Iran \\ Correspondence: Fatemeh Golshani, PhD of General Psychology, Department of Psychology, Faculty of \\ Education and Psychology, Islamic Azad University of Central Tehran Branch, Tehran, Iran. E-mail: \\ esfehani.mohamad3@gmail.com
}

Received: March 27, 2016

Accepted: April 26, 2016

Online Published: May 7, 2016

doi:10.5539/mas.v10n9p14

URL: http://dx.doi.org/10.5539/mas.v10n9p14

\begin{abstract}
Early maladaptive schemas are patterns or deep, pervasive and dysfunctionalthemes formed in childhood or adolescence, continue in adulthood and act at the deepest level of the cognition and usually the person is not aware of them. Schema makes people prone to aggression, depression, anxiety, poor interpersonal relationships and mental- physical disorders. The aim of this study is to compare early maladaptive schemas and the birth order of children in the formation of aggression. For this purpose, in an ex post facto research, 320 cases usingconveniencecluster sampling were selected from Tehran government girls' high schools and were tested. After screening, 160 only child students were selectedrandomly andwere assigned in the first group and in the second group 160 students of the rest were assigned who have been matched with the first group. One-way analysis of variance results showed that early maladaptive schemas and birth order, birth (one's position in the family) are involved in the creation of aggression. According to the findings, we can say that the early maladaptive schemas and birth order of childrenare important factors in the formation of aggression.
\end{abstract}

Keywords: early maladaptive schemas, birth order of children, aggression, high school students

\section{Introduction}

All children experience aggressive behaviors. It appears that aggression under the influence of time is transformed and during certain sections ofmental development, is intensive and more varied. However, the outbreak of externalizedbehaviorsin different ages doublesthe need for assessment and treatment planning of such behaviors. Otherwise, the aggressive behavior as stable personality traits can your affect other behaviors until adulthood (Kendall, 2000). Researchers have attributed aggressive behavior to various causes. So that some of them, have emphasized on the central role cognitive schema in preserving and stability of aggressive behavior in different time and situations. In this regard, Crick and Dodge 2 (1994) with suggesting the model of social information processing, have considered the role of mental structures, in particular cognitive schema in the regulation of aggressive behavior important.Hiosman (1988) also believes that aggressive behaviorsoccurdue to the internalization a large number of aggressive schemas in the structure of the person's mind.Ifthe rate ofcatching the human societies toa particular issueis a measure ofimportance of this issue, it can beclaimed aggression is one of the major and important issuesthat human beings of the distant past have extensively dealt with it and have now. A glimpse over stunning and increasing statistics of crimes and conflicts that occur in human societies, indicate that a major part of it is the result of aggressive behavior.

In fact the event aggression is a tendency or tension that in person that can be revealedin the forms of killing and destroy.In other words, aggression refers to behavior aimed at hurting themselves or others. According to Karimi (2010) in this definition, the intention of the person is important; that is aggressive behavior ifbe taken intentional and premeditated to hurt others or oneself.In another definition, aggression is used to describe a set of externalized behaviors that in all of them the characteristic abuses of other social rights and disturbing effect of this behavior is common.According to Baraheni (2009) aggressiveactions can also be physical and verbal behaviors of aggression such as threats, verbal dispute and razing people assets. Some psychologists know that 
aggressive behavior can harm or potential harm to others. Some psychologists consider aggression as a behavior that hurt others or potentially harm them. Aggression can be physical, verbal or otherwise violate the rights of others. These psychologists have distinguished between hostile aggression and instrumental aggression (Karimi, 2010).

On the other hand, many studies have shown that the presence of the aggressive child in each family affected the family structure and can affect on the mental health of the family specially the parents. Aggressive child due to cause severe conflicts among family membersinvolves the whole family in crisis. (Ahi, 2007).Family relationships may be weakened and emotional and aggressive child make lesions and irreversible effects on mental health of family including the escalation of marital discord, divorce, anxiety, embarrassment, and anger, and so on.In fact, researches have shown that parents of aggressive children are generally at risk in to encounter with problems of family life and emotional difficulties (Beckman 1, 1991; Singer and Orwin, 1998). Psychologists have long declared that parent's performance has a significant impact on the formation of thoughts, behavior and emotions of children. Based on vulnerability to psychopathology many researchershave investigated the role of family factors as the predisposing factorsin vulnerability of person (Harris and Kurten 4, 2002).Among them Piaget (1954) and Bowlby (1969) (quoted by Gantiand Buri, 2008) believe that the parent's performance causes formation and development of models within person cognitive structure named schema. These schemas in life act as lenses to make interpret, selection, and evaluate person of his experiences.Following the cognitive theories of mental vulnerability by borrowing from the perspective of Piaget, Young (1994) has developed a theory in relation to the early maladaptive schema. He believes that these schemas that are mentioned as "a structure or frame of reference", as are sustainable structures that aslenses affecton perception of person over the world, herself/himself and others. These schemas are formed during childhood experiences (mostly in children's lives have role of an intrinsic hit) and undermines an individual's response to environmental events. The main source of these schemas are basic emotional needs including five areas:secure attachment to others, such as sense of security, stability and acceptance, autonomy, competence and sense of identity, freedom of expression of needs and emotions, games and spontaneous and reasonable limits and self-control, early experience life, failure to satisfy basic needs, over-satisfaction and identification with the incorrect behavior of parents and child emotional temperament- a set of children emotional featuresthat are inherent and distinctive character of the child (Young 1994).These schemes are formed on the five fundamental developmental tasks that it is believed children need pass these tasks in relation to parents and the environment during their transformation. These five tasks are: disconnection and rejection, this category of schemes involves negative beliefs related to relationships that may affect one's expectations and conceptualization of relations. Here the core belief is that relationships are unreliable, invalid and unattainable.

Impaired autonomy and performance of this group primarily includes beliefs about oneself that individual consider himself/herself weak, ineffective and helpless and these schemas have important effects on the self-confidence of different areas of life. Impaired Limits; the schema of this category is related to appreciation, evaluation, and limitations of everyday life. Other directedness; this group of schemas is focused on ideas withthe contentthat only the needs, wants and feelings are important and are resulted in separation from others and rejectionof them. Over vigilance and inhibition, consists of unrealistic standards that are more related to tend to focus on the circumstances, outcomes and negative behaviors thanpositive conditions, output and behavior.

Schemes according five child developmental needshave been divided to five areas: rejection, impaired autonomy and Performance, impaired limits, other directedness and over vigilance and inhibition. (Young, 2003 Translated by Poorandooz, 2008).Rezai and Shams Alizadeh (2012) in a study concluded that there is a significant difference between aggressive students with normal group. So it seems maladaptive schema has a significant role in the propensity to aggression.On the other hand, Michael Gross, author of "Why first-borns rule the world and the last children want to change it" believes: a child's position in the family, affect his/her character, behavior, learning and earning power. Most people have an intuitive knowledge that birth order somehow impact on growth, but how important and meaningful of it less than what it is really is considered.

Conley also concedes that birth order is important in shaping individual success, but this is only for children of large families (with more than four children) and in families where finances and parental time are constrained. But in wealthy families, this influence is less.Adler approachspecified apsychological or appropriate status that children consider living from its ange: first child, second child of only nine children, the middle child, last child, only child.The birth order isn't a fatalist conception but increases the possibility a person tohave a certain experiences.Real birth order is less important than individual perception of its position in the family. Since most human problems are social in nature, it is stressed on relationships in family as the most basic andperhaps most influential social system.Adler noted that it is wrong to assume that the children in the unique family had been 
formed in the same environment. Although siblings in a family are common in some aspects but because of the birth order each child's psychological state is different from other (translated Seyyedmohammadi, 2015). Therefore it is necessary that psychological and environmental variables affecting the aggression to be recognized. Maladaptive schemas are cognitive, emotional and behavioral infrastructure. When schemas are activated levels of excitement to be spreadand, directly or indirectly led to various forms of psychological disturbances such as depression, anxiety, aggression, interpersonal conflicts, and like them. Maladaptive schema is not led to a specific mental disorder but increases an individual's susceptibility to mental disorders.

The birth order of childrenand individuals role and perception of their own position in the family in a way that adults interact in the lives, play an important role in psychopathology and formation of a variety of disorders. People learn specific style of interact with others in childhood and constitute a certain image of themselves transform it as their adulthood interactions.Therefore, working on family dynamics, especially the relationship between sisters - brothers (siblings) has an important role to understand how the character trends which during childhood have been started, as a result of competitive behavior and parents behavior with children affect people during life. Regarding thementioned issues, in current paper it is tried to be answered to the question whether the early maladaptive schema and birth order of children can be effective in their aggression?Schema can be described as cognitive structure for selection, encoding and evaluation the stimuli that affect on the organisms.

\section{Research Methodology}

This study sought to determine the effect of early maladaptive schemas and the birth order ofchildren on aggression. Research design is causal - comparative and two groups of only child students and a group of students who are third child onward of family were compared.The first group were selected randomly among all only child students and the second group was matched with it.

\subsection{Statistical Society}

The population of this study consisted of students in public girlsschools of 4 districts $(1,2,3,4)$ of Tehran in the academic year of 3015-2016. All students in all schools regardless of field of study were asked to fill the scale of aggression grading and early maladaptive schema.

\subsection{Sample Size and Sampling Method}

To collect research data from randomized cluster was used. That is fromselectedhigh schools in four districts of Tehran, a sample of 300 students wereselected randomly and in order to avoid the possible loss of them 320 questionnaires were administered. In the selecting samples randomness was regarded.

\subsection{Research Findings}

Descriptive indicators (mean and standard deviation):The scores of aggression questionnaire in students according to birth order are calculated and are presented in the table below. It is noteworthy that only child children have been studied as a separate group and the next group of children, including students who are third child onwards.

Aggression in first children, second and last is different. In order to study the difference between mean scores of aggression in students according to their birth order regardingthe effect of independent variable (which includes four group of only child, first child, second child and third child onwards) on the scores of dependent variable of aggression ANOVA test was used to compare mean of groups and the results are presented in the table below.

Table 1. The summary results of one-way analysis of variance (ANOVA) for aggression in terms of birth order

\begin{tabular}{lllllll}
\hline $\begin{array}{l}\text { significan } \\
\text { ce }\end{array}$ & F & $\begin{array}{l}\text { Mean } \\
\text { squares }\end{array}$ & df & sum of squares & $\begin{array}{l}\text { Changes } \\
\text { resource }\end{array}$ & variable \\
\hline 0.156 & 1.753 & 369.222 & 3 & 1107.666 & Inter-group & aggression \\
& & 210.631 & 291 & 61293.711 & Intra-group & total \\
\hline
\end{tabular}

Given thecalculated $F$ for aggression $(F(3.291=1 / 753, p>0 / 05)$ at $0 / 05$ is not significant. Therefore, between children aggression according to their birth order there isn't a significant difference.

Early maladaptive schemas in first children, second and last are different. In order to study the difference between mean scores of each early maladaptive schema in students in terms of their birth order regarding effect 
of the independent variable of birth order (which includes four group of only child, first child, second child and third child onwards) on the dependent variable due to lack ofassumption of homogeneity covariance matrix $(B o x=2132 / 877, F(360,106640 / 74)=5 / 33, p<0 / 01)$ multivariate analysis of variance MANOVA test wasn't used and instead of this test, ANOVA for comparison the mean of each of maladaptive schema according to students birth order individually was used,The summaryof the results of ANOVA is showed in following table.

Table 2.

\begin{tabular}{|c|c|c|c|c|c|c|c|}
\hline $\begin{array}{l}\text { significan } \\
\text { ce }\end{array}$ & $\mathbf{F}$ & $\begin{array}{l}\text { Mean } \\
\text { squares }\end{array}$ & df & $\begin{array}{l}\text { sum } \\
\text { squares }\end{array}$ & of & $\begin{array}{l}\text { Changes } \\
\text { resource }\end{array}$ & variable \\
\hline 0.873 & .234 & $\begin{array}{l}0.113 \\
0.482\end{array}$ & $\begin{array}{l}3 \\
291 \\
294 \\
\end{array}$ & $\begin{array}{l}.338 \\
140.180 \\
140.519 \\
\end{array}$ & & $\begin{array}{l}\text { Inter-group } \\
\text { Intra-group } \\
\text { total }\end{array}$ & $\begin{array}{l}\text { emotional } \\
\text { deprivation }\end{array}$ \\
\hline 0.131 & 1.891 & $\begin{array}{l}1.875 \\
0.992\end{array}$ & $\begin{array}{l}3 \\
291 \\
294 \\
\end{array}$ & $\begin{array}{l}5.625 \\
288.544 \\
294.170 \\
\end{array}$ & & $\begin{array}{l}\text { Inter-group } \\
\text { Intra-group } \\
\text { total }\end{array}$ & Triggered \\
\hline 0.243 & 1.400 & $\begin{array}{l}0.984 \\
0.703\end{array}$ & $\begin{array}{l}3 \\
291 \\
294 \\
\end{array}$ & $\begin{array}{l}2.951 \\
204.507 \\
207.457 \\
\end{array}$ & & $\begin{array}{l}\text { Inter-group } \\
\text { Intra-group } \\
\text { total }\end{array}$ & Distrust \\
\hline 0.004 & 4.506 & $\begin{array}{l}3.315 \\
0.736\end{array}$ & $\begin{array}{l}3 \\
291 \\
294 \\
\end{array}$ & $\begin{array}{l}9.945 \\
214.104 \\
224.049 \\
\end{array}$ & & $\begin{array}{l}\text { Inter-group } \\
\text { Intra-group } \\
\text { total }\end{array}$ & isolation \\
\hline 0.053 & 2.589 & $\begin{array}{l}1.598 \\
0.617\end{array}$ & $\begin{array}{l}3 \\
291 \\
294 \\
\end{array}$ & $\begin{array}{l}4.794 \\
179.605 \\
184.399 \\
\end{array}$ & & $\begin{array}{l}\text { Inter-group } \\
\text { Intra-group } \\
\text { total }\end{array}$ & deficiency \\
\hline 0.001 & 7.730 & $\begin{array}{l}4.659 \\
0.603\end{array}$ & $\begin{array}{l}3 \\
291 \\
294 \\
\end{array}$ & $\begin{array}{l}13.977 \\
175.399 \\
189.376 \\
\end{array}$ & & $\begin{array}{l}\text { Inter-group } \\
\text { Intra-group } \\
\text { total }\end{array}$ & Failure \\
\hline 0.009 & 3.948 & $\begin{array}{l}2.448 \\
0.620\end{array}$ & $\begin{array}{l}3 \\
291 \\
294 \\
\end{array}$ & $\begin{array}{l}7.343 \\
180.417 \\
187.760 \\
\end{array}$ & & $\begin{array}{l}\text { Inter-group } \\
\text { Intra-group } \\
\text { total }\end{array}$ & Dependence \\
\hline 0.088 & 2.202 & $\begin{array}{l}1.539 \\
0.699\end{array}$ & $\begin{array}{l}3 \\
291 \\
294 \\
\end{array}$ & $\begin{array}{l}4.616 \\
203.284 \\
207.900 \\
\end{array}$ & & $\begin{array}{l}\text { Inter-group } \\
\text { Intra-group } \\
\text { total }\end{array}$ & $\begin{array}{l}\text { Undeveloped } \\
\text { Self }\end{array}$ \\
\hline 0.002 & 5.185 & $\begin{array}{l}4.229 \\
0.816\end{array}$ & $\begin{array}{l}3 \\
291 \\
294 \\
\end{array}$ & $\begin{array}{l}12.688 \\
237.375 \\
250.063 \\
\end{array}$ & & $\begin{array}{l}\text { Inter-group } \\
\text { Intra-group } \\
\text { total }\end{array}$ & sacrifice \\
\hline 0.504 & .783 & $\begin{array}{l}0.538 \\
0.686\end{array}$ & $\begin{array}{l}3 \\
291 \\
294 \\
\end{array}$ & $\begin{array}{l}1.613 \\
199.728 \\
201.341 \\
\end{array}$ & & $\begin{array}{l}\text { Inter-group } \\
\text { Intra-group } \\
\text { total }\end{array}$ & obedience \\
\hline 0.008 & 4.052 & $\begin{array}{l}2.881 \\
0.711\end{array}$ & $\begin{array}{l}3 \\
291 \\
294 \\
\end{array}$ & $\begin{array}{l}8.644 \\
206.897 \\
215.540 \\
\end{array}$ & & $\begin{array}{l}\text { Inter-group } \\
\text { Intra-group } \\
\text { total }\end{array}$ & entitlement \\
\hline 0.272 & 1.306 & $\begin{array}{l}0.867 \\
0.664\end{array}$ & $\begin{array}{l}3 \\
291 \\
294 \\
\end{array}$ & $\begin{array}{l}2.602 \\
193.161 \\
195.762 \\
\end{array}$ & & $\begin{array}{l}\text { Inter-group } \\
\text { Intra-group } \\
\text { total }\end{array}$ & $\begin{array}{l}\text { Emotional } \\
\text { inhibition }\end{array}$ \\
\hline 0.001 & 6.747 & $\begin{array}{l}5.650 \\
0.837\end{array}$ & $\begin{array}{l}3 \\
291 \\
294\end{array}$ & $\begin{array}{l}16.949 \\
243.681 \\
260.630\end{array}$ & & $\begin{array}{l}\text { Inter-group } \\
\text { Intra-group } \\
\text { total }\end{array}$ & Strict criteria \\
\hline
\end{tabular}

As can be seen in the table regarding the calculated $\mathrm{F}$ for maladaptive schemas of isolation $(\mathrm{F}(3,291)=4 / 506$, $p<0 / 05)$, failure $(F(3,291)=7 / 730, p<0 / 05)$, dependence $(F(3,291)=3 / 948, p<0 / 05)$, sacrifice $(F(3,291)=5 / 185$, $p<0 / 05)$, entitlement $(F(3,291)=4 / 052, p<0 / 05)$ and strict criteria $(F(3,291)=6 / 747, p<0 / 05)$, at $0 / 05$ is significant, therefore, between the EMSs ofisolation deficiency, failure, dependence, sacrifice, entitlement and strict criteria in students in terms of birth order there is a significant difference.Generally, scores of all early maladaptive 
schema except triggered and deficiency, in one child students is more compared to other multiple-childstudents. In order to evaluate the significant difference between the mean of four groups given heterogeneous sample size of groups according Scheffe test was used. The results are presented in the table below.

Table 3. Scheffepost hoc test

\begin{tabular}{|c|c|c|c|c|}
\hline significance & standard error & mean difference & Groups & Sub-scale \\
\hline 0.111 & 0.15750 & 0.38755 & only child- first child & \\
\hline 0.614 & 0.15879 & 0.21352 & only child- second child & isolation \\
\hline 0.010 & 0.15983 & $0.54361 *$ & only child- next child & \\
\hline 0.627 & 0.13161 & -0.17403 & only child- second child & \\
\hline 0.711 & 0.13287 & 0.15606 & only child- next child & \\
\hline 0.113 & 0.13439 & 0.33009 & second child- next child & \\
\hline 0.001 & 0.14256 & $0.62050 *$ & only child- first child & \\
\hline 0.009 & 0.14372 & $0.49290 *$ & only child- second child & Failure \\
\hline 0.001 & .14467 & $0.63556 *$ & only child- next child & \\
\hline 0.766 & 0.11912 & -0.12759 & only child- second child & \\
\hline 0.999 & 0.12026 & 0.01506 & only child- next child & \\
\hline 0.712 & 0.12164 & 0.14265 & second child- next child & \\
\hline 0.869 & 0.14458 & 0.12264 & only child- first child & \\
\hline 0.948 & 0.14576 & 0.08751 & only child- second child & Dependence \\
\hline 0.039 & 0.14672 & $0.42729 *$ & only child- next child & \\
\hline 0.994 & 0.12081 & -0.03513 & only child- second child & \\
\hline 0.103 & 0.12197 & 0.30465 & only child- next child & \\
\hline 0.058 & 0.12337 & 0.33978 & second child- next child & \\
\hline 0.031 & 0.16584 & $0.49667 *$ & only child- first child & \\
\hline 0.002 & 0.16720 & $0.64185^{*}$ & only child- second child & sacrifice \\
\hline 0.023 & 0.16830 & $0.52417 *$ & only child- next child & \\
\hline 0.778 & 0.13858 & .14518 & only child- second child & \\
\hline 0.998 & 0.13990 & 0.02750 & only child- next child & \\
\hline 0.875 & 0.14151 & -0.11768 & second child- next child & \\
\hline 0.511 & 0.15483 & 0.23536 & only child- first child & \\
\hline 0.016 & 0.15610 & $0.50517 *$ & only child- second child & entitlement \\
\hline 0.739 & 0.15712 & 0.17632 & only child- next child & \\
\hline 0.229 & 0.12938 & 0.26980 & only child- second child & \\
\hline 0.977 & 0.13061 & -0.05904 & only child- next child & \\
\hline 0.105 & 0.13211 & -0.32885 & second child- next child & \\
\hline 0.001 & 0.16803 & $0.67429 *$ & only child- first child & \\
\hline 0.001 & 0.16940 & $0.70399 *$ & only child- second child & Strict criteria \\
\hline 0.026 & 0.17052 & $0.52181 *$ & only child- next child & \\
\hline 0.998 & 0.14041 & 0.02970 & only child- second child & \\
\hline 0.763 & 0.14175 & -0.15249 & only child- next child & \\
\hline 0.656 & 0.14338 & -0.18218 & second child- next child & \\
\hline
\end{tabular}

The results of table 1.7 shows that in the scheme of isolation and dependence only between the two groups of one child students with the third child onwards there is a significant difference, so that the mean of isolation and dependence schema in a onlychild children is higher than of third child onwards.

In the scheme of failure, sacrifice and strictcriteria between groups of one child students andfirst child students, second and third child onwards there is a significant difference, so that the mean of sacrifice, failure and strict criteria schema in only child children is higher than other groups.

In the scheme ofentitlement only between two groups of one child students and second child students there is a significant difference with so thatmean of entitlement schema inonly child children is higher than second children.

Given that maladaptive thoughts are initial thoughts that have been shaped in the developmental period of growth can create maladaptive schemas that have a major role in aggression.Verbal aggression is one of the most 
common disorders, which cause many social psychological problems for children. Aggression in children negatively impresses the social, personal, family and educational performance of children and adolescents.This study intends by express different definitions and perspectives to investigate the causes of aggression in female high school students. The main purpose is identifyingmaladaptive schemain the formation of character and aggression by taking into account the birth order of children in the family.Family is semi-closed systemthat plays the role of internal communication has members with various officials and positions in the family and the community.Also considering the role of members and kinship relationshipsapproved by family members, will play a role (Rogers 1,1964$)$ just because the family will be the first social environment in people's lives. People learn a lot of things in this environment and in the early years of their social life and family through different ways cause or aggravate aggression in them. Failure and frustration will occur when a person fails to achieve his/her target interest or, in other words, the aggression is natural reaction against the failure (Karimi, 2001).

\section{Discussion and Conclusion}

Considering that the early maladaptive schema and birth order of children can be predictors of aggression in children, maladaptive schemas are deep cognitive include beliefs about self. The schemata are structures of reality that develop as a result of objective experiences of environment and specifically ones have been developed in early life have more significant effects.Schema development often is traced in childhood. Some people due to negative childhood make early maladaptive schemas that will affect on their way of thinking, feeling and behavior in next friendly relations and other aspects of lives.Disordersthat occur in the early stages of lifeaffects on information processing in the later stages of life and as a result individual will be vulnerable to the threat of abandonment. It also seems one of the primary affecting factors of aggression is early maladaptive schema. Schemas, drafts and beliefs susceptible to aggression may be learned in the family through family members and relationships that parents have established with children. Although the role of schemas and social information processing model is explained but put it under a separate title is further underscored the importance of it. Aggressive children and adolescents when processing social information activate schemes that issue aggression instruction and lead to aggressive behavior.

The birth order of children and individuals role and perception of their own position in the family in a way that adults interact in the lives, play an important role in psychopathology and formation of a variety of disorders.People learn specific style of interact with others in childhood and constitute a certain image of themselves transform it as their adulthood interactions.Early maladaptive schemas in first,second and last child is different.

According to descriptive datain one child students due to supports, cares and attention of parents and lack of next children caused the failure of first child aggression is less than other multiple children students. While the mean of isolation and dependence schema in only child is higher than the third child onwards. On the other hand, it seems that the sequence of children can be one of the factors explainaggression and birth order is an important factor in the formation of character and social birth order is an important factor in a person's childhood and life style that mayshape result of the early education of children with social interaction of lifestyle and individuals behaviors.

Hypotheses and questions is as follows: Hypothesis 1 that: There is a relationship between aggression and the birth order of children is approved. According to the results obtained in this study aggression is different in terms of birth order of students. The Students birth order and perception of their own position in the family in a way that adults interact in the live play an important role in psychopathology and formation of a variety of disorders especially aggression.According to research conducted by Paterson and colleagues (1992) it was showed that the formation of attitudes, schemaand gradual beliefs is more in abandoned children so negative experience of feeling of rejection play an important role in building cognitive relationship underlying caused by aggressive behavior.In a research titled the identification a relationship between parenting styles with studentsaggression by Hosseini-gheydari (2015) it was showed that there is a significant positive relationship between authoritarian parenting practices and students' aggression.In another study titled the relationship between parenting styles with female students aggression it was showed there isn't a significant relationship between democratic parenting style with aggression and in fact, democratic reduces the aggression but neglectful style and especially, authoritarian style increase teenage girls' aggression.Conclusion: It can be argued that the best style to reduce aggression in adolescent girlsis democratic style.This style (democratic) represents appropriate interaction with intimacy and at the same time, fair and realistic controls, but neglectful and authoritarian parenting style reflects the inappropriate interaction and unreasonable control of children.To explain these findings, it can be said that aggression is a result of failures that children experience inthe childhood, in other words failure is a necessary and sufficient condition for the occurrence of aggression. The families first and most importantly influence on 
children and relationship between parents and children is responsible for shaping aggressive behavior.

Hypothesis 2 stating that: between the early maladaptive schemas of students according to their birth order there is a significant difference is confirmed.The results obtained in this study showed maladaptive schemas are differentin terms of birth order. So,early maladaptive schemas are based on children sequence of birth.Castile, Prot, Maszik, Eshmidz (2006) in their studies showed that only child children with self-mutilation behaviors had more early maladaptive schemas. The results of schema-based studies on non-clinical adolescents in relation to the parents perceived by Morris (2006) showed that develop parents detrimental nurturing behaviors associated with early maladaptive schemas. Other research results by Paterson and colleagues (1992) showed that the formation of prescriptive attitudes, schemas and beliefs of abandoned children are more in large families. The negative experience of feeling of being rejected plays an important role in creating cognitive infrastructure of aggressive behavior.

Given the participants in this study consisted of all high school students in the district 4, 3, 2 and 1 of Tehran can prevent the generalization of the results to all high school students in all districtsand due to the large number of questions and low motivation or lack of understanding of some questions, inquiries discreet conclusions from the results. Also participants were all female high school students that can prevent a generalization of the results to male students in all parts of city. It is suggestednext in next research other regions in Tehran are regarded. Considering the samples of this researchwere ordinary people it is suggested that national and regional programs in order to control their aggression to be learned. Given the results of this research can be said with identification early schema it is recommended prior to aggressiveness that affectedby schema by specifying schema pattern among students appropriate intervention strategies be taken in order to reduce aggression and parents by providing space satisfy their own and their children aggression in a positive way.With respect to the sampling in current study was convenience, it is recommended that random sampling to be used in future research.

\section{References}

Ahi, G. (2007). Standardization of short version of the Young Schema questionnaire.Master's thesis in General Psychology, AllamehTabatabaei University.

Atkinson, R. E., et al. (1380). Hilgard's Introduction to Psychology, translated by Mohammad NaghiBaraheni et al., Tehran, Roshd publication).

Baranoff \& Tian (2007). Young Schema Questionnaire: Review of psychometric andmeasurement issues. Australian Journal of Psychology, 59, 2, 78 - 86.

Buri (1997) . Parental authority questionare. Journal of Personality Assessment, 57,110-119.

Cecero, \& Young (2001). Case of Silvia: A Schema-Focused Approach. Journal of Psychotherapy Integration, 11(2), 217-229.

Crick. N. R., \& Dodge. K. A. (1994). A review \& reformulation of social information processing mechanismsin children adjustment. Psychological Bulletin, 115, 74-101.

Diaz, Y. (2005). Association between parenting and child behavior problems amongLatino mothers and children. Unpublished Master Thesis, University of Maryland,

Gunty, B. (2008). Parental Practices and the Development of Maladaptive SchemasOnline Submission, Paper presented at the Annual Meeting of the MidwesternPsychological Association (Chicago, IL, May 2008). 33 pp.

Harris, \& Curtin (2002). Parental Perception, Early Maladaptive Schemas andDepressive Symptoms in Young Adult. Cognitive Therapy and Research, 26(3), 405-4

Hosseini-gheidari, A. (2005). Investigation of relationship between Parenting Styles and elementary students aggression. (Master of Science and Research of Kerman)

Huesmann, L. R. (1998). An information- processing model for the development of aggression. Aggression Behavior, 14, 13-24.

Jeffrey, Y., Jeanette, G., \& Marjorie, V. (9001). Schema therapy. H. Hamidpour. Z Anduz (2011) Tehran, Arjmand publication).

Karimi, Y. (2002). Social psychology. Thran: Arasbaran.

Kendall, P. C. (2000). Childhood disorder. New York. Academic Press.

Laura, B. (2009). Developmental Psychology (from conception to childhood). Translation:Yahya Syed 
Mohammadi. Tehran: Arasbaran

Morris, S. (2008). Development of interpersonal aggression scale for people with intellectual and developmental disabilities. Doctor of philosophy dissertation. Ohio state university.

Patterson. G. R., Reid, J. B., \&Dishion, T. J. (1992). Antisocial boys. Eugene, or: Oregon, Social Learning Center \& Castilian Publishing Co.

Young, J. E. (1999). Cognitive Therapy for Personality Disorders: A Schema- Focused Approach (9rd Ed). Professional Resource Press.

\section{Copyrights}

Copyright for this article is retained by the author(s), with first publication rights granted to the journal.

This is an open-access article distributed under the terms and conditions of the Creative Commons Attribution license (http://creativecommons.org/licenses/by/3.0/). 